\title{
Constitutional Compliance Solution to Law Testing Rulings in the Constitutional Court
}

\author{
Tri Sulistyowati ${ }^{1}$ \\ Ali Rido ${ }^{2}$ \\ M. Imam Nasef ${ }^{3}$
}

\begin{abstract}
1 Faculty of Law, Universitas Trisakti, Indonesia. E-mail: tri.s@trisakti.ac.id
${ }^{2}$ Faculty of Law, Universitas Trisakti, Indonesia. E-mail: alirido@trisakti.ac.id

${ }^{3}$ Faculty of Law, Universitas Trisakti, Indonesia. E-mail: imamnasef@gmail.com
\end{abstract}

\section{Article Info}

\begin{tabular}{l}
\hline Keywords: \\
Constitutional Court; \\
Constitutional \\
Compliance; Addressat \\
Verdict \\
How to cite (APA Citation \\
Style): \\
Sulistyowati, Tri., et. Al. \\
(2021). "Constitutional \\
Compliance Solution to \\
Law Testing Rulings in \\
the Constitutional Court". \\
Jambura Law Review. \\
JALREV 3 Special Issue: \\
117-134
\end{tabular}

\begin{abstract}
One of the current constitutional issues in Indonesia is the non-compliance of the decision to immediately follow up the decision of the Constitutional Court, which is final. This paper aims to analyze forms of non-compliance with the decision of the Constitutional Court and create a model that is expected to be a solution to the problem. This type of research is juridical normative by using secondary data processed by editing and systematization techniques. The results showed the form of noncompliance of the decision of the Constitutional Court by the addresat of the decision is manifested in 3 (three) forms, namely normative, praxis, and normative and praxis forms. There are three proposed state-regulation solutions, namely judicial deferral by limiting the time of action, reaffirmation of judicial restraint, collaborative action, and collective awareness between state institutions.
\end{abstract}




\section{Introduction}

Post-reform, Indonesia has expressly exposed itself as a country that adheres to the supremacy of the constitution in the state. Therefore, the Constitution of the Republic of Indonesia of 1945 as a form of a written constitution in the hierarchy of legislation is placed on the highest hierarchy. The consequences of the position of the 1945 Indonesian Constitution as the highest law cause the law not allowed to contradict the fundamental law because the constitutional system in itself contains constitutional testing of established norms. ${ }^{1}$

Indonesia established a Constitutional Court whose authority to test the law against the 1945 NRI Constitution. Constitutional testing by the Constitutional Court of the Republic of Indonesia is final. The final diction is interpreted as the last of the series of examinations. ${ }^{2}$ According to Soemantri, the final award must be binding and cannot be overturned by any institution. ${ }^{3}$ Theoretically and conceptually, the final ruling means that the constitutional Court's decision is the first resort and the last resort for justice seekers. ${ }^{4}$ Thus, the decision of the Court of Justice must be respected and implemented by the government and other state institutions and society in general that are bound by the award (addressat verdict). The final nature of the decision of the Court of The Republic of Indonesia is inseparable from the agreement to establish the Court of Justice as a judiciary at the first and last level that has consequences that no legal mechanism in other courts can compare or correct verdict. ${ }^{5}$ The background of the situation, making the intent of the decision of the Court of Indonesia directly has a binding legal force, and there is no room for efforts in making other legal efforts. It was intended so that the Court of Justice can resolve state regulation can immediately provide legal certainty following the principles of a quick and straightforward judiciary.

\footnotetext{
1 Maruarar Siahaan, (2005). "Hukum Acara Mahkamah Konstitusi Republik Indonesia", 1 ${ }^{\text {st }}$ Edition. Jakarta: Konstitusi Press. p. 4.

2 Anonymous. (2001). "Kamus Besar Bahasa Indonesia". Jakarta: Departemen Pendidikan Nasional dan Balai Pustaka. p. 317.

3 Ni'matul Huda, (2018). “Kekuatan Eksekutorial Putusan Mahkamah Konstitusi”. Yogyakarta: FH UII Press. p. 141.

4 Bambang Sutiyoso. (2006). "Hukum Acara Mahkamah Konstitusi Republik Indonesia", Cetakan Pertama, Bandung: PT. Citra Aditya Bakti. p. 160.

${ }^{5}$ Fajar Laksono Soeroso. (2004). "Aspek Keadilan dalam Sifat Final Putusan Mahkamah Konstitusi", Jurnal Konstitusi. 11 (1): 77.
} 
Given the decision of the Court of Justice with the final fission, it becomes the obligation of all elements of the nation and the state to carry it out consequently. In its development, compliance of state institutions in implementing the decision of the Court of Justice becomes an issue. Against some decisions of the Court of Justice, the institution that addressed the decision did not implement and even ignored the verdict, for example: first, the Decision of Constitutional court No. 5/PUU-X/2012 on the testing of Article 50 paragraph (3) of Law No. 20 of 2003 on the National Education System. Although the provision has been declared unconstitutional, the government, through the Ministry of Education and Culture, is still pursuing a transitional policy to remove the policy of International Standard Schools (SBI) and/or International School Pilots (RSBI).

Second, the Decision of the Constitutional Court No. 36/PUU-X/2012 concerning Oil and Gas Cooperation Contracts in which the position of the Upstream Oil and Gas Business Implementation Agency (BP Migas) has been declared unconstitutional, but then the government established a Special Working Unit for Upstream Oil and Gas Business Activities (SKK Migas) which substantively performs the same functions as BP Migas. Third, the Decision of the Constitutional Court No. 92-PUU-X-2012 essentially makes the Regional Representative Council equivalent to the President and the House of Representatives in the state of submission and discussion of the draft law. Nevertheless, the President and the House of Representatives were ignored by re-ruling the Regional Representative Council. It was seen in the revision of Law No. 42 of 2014 to Law No. 17 of 2014, in which legislators re-entered norms that have been declared unconstitutional by the Constitutional Court. Fourth, the Decision of the Constituent Assembly No. 34/PUU-XI/2013 essentially states that a review can be done more than once. The decision has revoked Article 263 paragraph (3) of Law No. 8/1981 on the Criminal Procedure Law. Fifth, The Decision of Constitutional court No. 30/PUU-XVI/2018 requires that Regional Assembly senators not be from the management (functionaries) of political parties. However, the Supreme Court in Decision No. 65 P/HUM/2018 ignored the decision of the Court of Justice.

Various forms of non-compliance with the decision of the Court of Justice certainly can be categorized as constitutional compliance that can threaten the supremacy of 
the constitution. ${ }^{6}$ The constitution or verfassung is considered the highest political decision so that the constitution has a position or degree of supremacy in a country. In other words, the supremacy of the constitution is where the supreme constitution position in the rule of law of a country. ${ }^{7}$

In order to provide a differentiator picture of existing research, the following description can be given:

1. Firmansyah Arifin, Firmansyah Arifin, Agil Oktaryal Andri Gunawan, \&Erwin Natosmal Oemar. ${ }^{8}$ The study, focusing more on the model of the decision decided by the Court of Justice and the description of the implementation of the verdict that has been done by addressat the verdict through various laws and regulations.

2. Novendri M. Nggilu. ${ }^{9}$ In the study, there is one subject about the forms of action constitution disobedience against the decision of the Constitutional Court. However, the discussion has not mapped into the form of normative, praxis, and normative and praxis actions as the author did. In addition, the range of decisions of the Court of Justice analyzed was also taken at random.

3. M. Agus Maulidi. ${ }^{10}$ Although one of the subjects is similar, but the subdiscussion is actually more focused on comparison with the supreme constitution in other countries in an effort to create a final and binding ruling on the implementative Indonesian Court.

4. Syukri Asy'ari, Meyrinda Rahmawaty Hilipito, \& Mohammad Mahrus Ali. ${ }^{11}$ The focus of the research is on the characteristics of the decision decided by the

\footnotetext{
${ }^{6}$ Jimly Asshidiqie. (2012). "Perkembangan \& Konsolidasi Lembaga Negara Pasca Reformasi”, 2nd edition. Jakarta: Sinar Grafika. p. 12.

7 Parlin M. Mangunsong. (1992). "Konvensi Ketatatnegaraan Sebagai Salah Satu Sarana Perubahan UUD". Bandung: Alumni. p. 22.

${ }^{8}$ Firmansyah Arifin, et.al., (2019). "Implementasi Putusan Pengujian Undang-Undang oleh Mahkamah Konstitusi 2003-2018”. Jakarta: Indonesian Legal Roundtable.

9 Novendri M. Nggilu (2019). "Menggagas Sanksi atas Tindakan Constitution Disobedience terhadap Putusan Mahkamah Konstitusi". Jurnal Konstitusi. 16 (1).

${ }^{10}$ M. Agus Mauldi. (2019). "Menyoal Kekuatan Eksekutorial Putusan Final dan Mengikat Mahkamah Konstitusi". Jurnal Konstitusi. 16 (2).

${ }^{11}$ Syukri, A., Meyrind, R.H., Mohammad, M.A., (2013). "Model dan Implementasi Putusan Mahkamah Konstitusi dalam Pengujian Undang-Undang (Study Verdict of 2003-2012)". Jakarta: Mahkamah Konstitusi RI. See also Syukri, A., Meyrind, R.H., Mohammad, M.A., (2015). "Tindak Lanjut Putusan
} 
Court of Justice and the characteristics of its implementation are manifested in the following form: a). Implementation of direct (self-executing); b). Non-self executing implementation. Thus, the study has not discussed related solutions to the decision of the Court of Justice that is not followed up by the addressat of the verdict.

As for the differentiator in this paper, it is as follows: 1). The focus of the study is on mapping the model of non-compliance addressat the verdict on the decision of the Court of Justice; 2). This study systematically and periodically studied the Court's decision from 2013-2018; 3). Model or solution of the strictness of the noncompliance addressat of the award focused on implementing the decision testing the law.

\section{Problem Statement}

The focus of the issue studied is how forms of non-compliance with the decision of the Constitutional Court of the Republic of Indonesia and how a solution to the state regulation can be taken on the non-compliance of state institutions against the decision of the Constitutional Court of Indonesia.

\section{Methods}

This type of research is juridical-normative research, so the material used is library material or secondary data collected by tracing the decision of testing the law by the Constitutional Court of the Republic of Indonesia period 2013-2018, which Amar verdict is granted. Then, it is also traced how the implementation of the decisions by the state institutions that become addressat. The data that has been obtained, then processed by: 1) editing, namely by checking and re-examined about its completeness, clarity, and truth, to avoid deficiencies and errors; 2) systematization, namely by conducting the preparation and placement of data on each subject systematically. As for the analysis of the data, qualitative analysis methods are used.

Mahkamah Konstitusi yang Bersifat Konstitusional Bersyarat Serta Memuat Norma Baru", Jurnal Konstitusi. 12 (3): 653. 
4. Forms and Solutions of State Regulation for Non-Compliance with the Decision of the Constitutional Court of the Republic of Indonesia

\subsection{Non-Compliance Addressat Verdict in Implementing the Decision of Testing} the Law in the Constitutional Court of the Republic of Indonesia Period $2013-2018$

The constitutional vision of the Republic of Indonesia is to uphold the constitution to realize the state of law and democracy for the sake of a dignified national and state life. The vision became a guideline for the Constitutional Court in exercising the judiciary's power that it held independently and responsibly following the Constitution of the Republic of Indonesia of 1945. ${ }^{12}$ Therefore, it is appropriate that every decision born from the Constitutional Court of the Republic of Indonesia is directly obeyed by every state and society, especially against testing the law. According to Asshiddiqie, the authority to test the law's constitutionality is precisely the most important, without downplaying the importance of other authorities of the five authorities owned by the Constitutional Court of the Republic of Indonesia. ${ }^{13}$

The decision of the Court of Justice, which is the result of interpretation of the constitution, becomes an obligation to be obeyed instead of betrayed by committing insubordination to the verdict. Submission to the decision of the Constitutional Court of Indonesia will indicate the implementation of the state based on the line of the constitution as the highest law. Concerning the obligation to obey the decision of the Court of Justice, it is in line with Jutta Limbach's opinion on 3 (three) main characteristics that mark the principle of constitutional supremacy, namely: ${ }^{14} 1$ ). The distinction between constitutional legal norms and other legal norms; 2). Binding of lawmakers by the constitution; and 3). There is one institution that has the authority to test the constitutionality of government legal actions or legislators.

12 Bambang Sutiyoso. (2011). "Pembentukan Mahkamah Konstitusi Sebagai Pelaku Kekuasaan Kehakiman di Indonesia." Jurnal Konstitusi, 7 (6): 26.

${ }^{13}$ Bachtiar. (2015). "Problematika Implementasi Putusan Mahkamah Konstitusi Pada Pengujian UU Terhadap UUD”. Jakarta: Penebar Swadaya Grup. p. 116.

${ }^{14}$ Jutta Limbach. (2001). "The Concept of the Supremacy of the Constitution". The Modern Law Review. 64 (1): 3. See also Fadjar L.aksono Soeroso, et.al., (2013). "Implikasi dan Implementasi Putusan Mahkamah Konstitusi Nomor 5/PUU-X/2012 tentang SBI atau RSBI". Jurnal Konstitusi. 10 (4): p. 741. 
In other words, if there is a state institution that does not implement or even overturn the decision of the Constitutional Court, then just as the state institution has ruled out the constitution as the highest law in the state. Nevertheless, the research conducted by the authors shows that there are still some constitutional court rulings that are not obeyed. Based on the results of the mapping conducted by the author, there is a form of non-compliance with the decision of the Constitutional Court that is manifested in various forms as follows: first, non-compliance with the decision of the Court of Justice in the form of normative. This form of non-compliance manifested in the form of follow-up to the legislation. Second, non-compliance with the decision of the Court of Justice in the form of praxis. In this aspect, the form of indifference is manifested in state practice in both the executive, legislative and judicial domains or practices in local government. Third, non-compliance with the decision of the Constitutional Court in the form of normative and praxis. This dimension illustrates that not only not obeyed in terms of normative but at the praxis level, the decision of the Constitutional Court is also not obeyed.

Concerning the form of non-compliance with the decision of the Constitutional Court in the normative form, among others seen in the decision of the Constitutional Court as follows:

1) Decision of Constitutional court No. 95/PUU-XIV/2016. The decision of this Court states that the right to organize Special Education of Profession Advocates is an advocacy organization. However, in the Regulation of the Minister of Research, Technology, and Higher Education No. 5 of 2019 concerning The Advocate Profession Program, it determines the organizer of PKPA is Higher Education.

2) Decision of Constitutional court No. 39/PUU-XIV/2016. The essence of the ruling, the Court stated that "basic goods that are needed by the people are much needed" in the Explanation of Article 4A paragraph (2) letter b law No. 42 of 2009 should not be interpreted limitatively. Against the ruling, in Government Regulation No. 145 of 2000 jo. Government Regulation No. 12 of 2006 concerning Group of Taxable Goods Classified as Luxury Subject to Sales Tax on Luxury Goods has not adjusted to the decision of the Court of Justice 
because it still includes essential goods that the people need are still interpreted limitatively.

Moreover, the non-compliance of the decision of the Court of Indonesia in the form of normative is seen in 1). The decision of Constitutional court No. 88/PUU-XIV/2016 is normatively not adhered to in local regulations; 2). The decision of Constitutional court No. 8/PUU-XIII/2015 is normatively not adhered to in the form of government regulations; 3). The decision of Constitutional court No. 19/PUU-XII/2014 is normatively not adhered to in the form of government regulations; 4). The decision of Constitutional court No. 82/PUU-XII/2014 is normatively not adhered to in the amendment of the law; 5). The decision of Constitutional court No. 83/PUU-XI/2013 is normatively not adhered to in the form of law; 6). The decision of Constitutional court No. 34/PUU-XI/2013, which is normatively a form of non-compliance, is manifested in the form of a Circular Letter of the Supreme Court; 7). The decision of Constitutional court No. 3/PUU-XI/2013 is normatively not adhered to in the form of law, and 8). The decision of Constitutional court No. 1/PUU-XI/2013 is normatively not adhered to in the form of revision of the law. Meanwhile, concerning noncompliance with the decision of the Constitutional Court in the form of practice, among others, namely:

1) The decision of the Constitutional Court No. 77/PUU-XIV/2016. The decision of the Constitutional Court states the phrase "can be reappointed" in Article 33 of Law No. 14 of 2008 on Public Information Disclosure is conditionally contrary to the 1945 NRI Constitution and does not have binding legal force as long as it is not interpreted as "re-elected through a selection process as stipulated in Article 30 and Article 32 of Law No. 14 of 2008 on Public Information Disclosure". Against the verdict, not obeyed, for example, seen related to the second period of the Gorontalo Information Committee members, which was not done through open selection. However, the Governor of Gorontalo only issued Decree No. 323/11/VIII/2015 concerning the Appointment of Members of the Gorontalo Information Committee Period 2015-2019, dated August 13, 2015. The decree also sued the State Administrative Court. However, the final verdict at the cassation level rejected 
the lawsuit (Case Verdict No. 287 K/TUN/2017, dated August 1, 2017). Thus, members of the Gorontalo Province KI were reappointed for a second period without a selection process. The form of non-compliance is manifested praxis in administering the state and the judicial process/court decisions.

2) Decision of Constitutional court No. 30/PUU-XVI/2018. This ruling Constitutional court states the phrase "other work" in Article 182 letter l of Law No. 7 of 2017 on Elections. The form of non-compliance with the decision of the Court of Justice, as evidenced in the Supreme Court of The Republic of Indonesia No. 65 P/HUM/2018, actually canceled the Election Commission Regulation No. 26/2018. Thus the form of non-compliance is manifested praxis in the process or court decision.

Then, concerning non-compliance with the decision of the Court of Justice in the form of normative and praxis are as follows: first, the Decision of Constitutional court No. 61/PUU-XV/2017 and 66/PUU-XV/2017. The two decisions of the Indonesian Court of Justice essentially reaffirmed the institutional existence of elections in Aceh, which is special in the form of the Independent Commission for Elections of Aceh Province, the Independent Commission for District/Municipal Elections, the Aceh Provincial Election Supervisory Committee, and the District/Municipal Election Supervisory Committee. Non-compliance in terms of normative, seen in the Regulation of the Election Supervisory Board (Perbawaslu) No. 10 of 2018 concerning Amendments to The Regulation of the Election Supervisory Board No. 19 of 2017. The essence of Election Supervisory Regulation, equating election organizers in Aceh with election organizers in other regions. Then non-compliance in its praxis is through Letter No. 0214 / BAWASLU / SJ / HK.01.00 / IV / 2018 dated April 12, 2018, which appoints the Election Supervisory Committee Aceh recruited and selected by Indonesian Election Supervisory Body. The decision of the Indonesian Court of Justice confirms that Election Supervisory Committee was proposed by the DPRA/DPRK following Article 44 to Article 47 of Qanun Aceh Number 6 of 2016 concerning The Organizers of Elections and Elections in Aceh junction Article 60 of Law No. 11/2016 of the Government of Aceh. 
Second, The Decision of Constitutional court No. 10/PUU-XV/2017. This ruling states Article 14 paragraph (1) letter a law No. 29 of 2004 concerning Medical Practice which states "The number of members of the Indonesian Medical Council 17 (seventeen) persons consisting of elements derived from: (a) the organization of the medical profession 2 (two) people; ..." contrary to the 1945 Indonesian Constitution and does not have binding legal force as long as the element of "medical profession organization" is not interpreted as not being the administrator of the medical professional organization.

Against the ruling, there has been no follow-up from the Government and parliament to revise the Law. In addition, there has been no revision to the Regulation of the Indonesian Medical Council No. 1 of 2011 concerning the Organization and Working Procedure of the Indonesian Medical Council, which includes a clause on the prohibition of Indonesian Health Commission members from elements of Indonesian Doctor Association or other medical professional organizations. Meanwhile, until now, Indonesian Health Commission membership still consists of 17 (seventeen) people, including the Indonesian Doctors Association.

The verdict of the Court that is not adhered to normatively and other praxis, namely: 1). Decision Constitutional court No. 100/PUU-XI/2013; 2). The decision of Constitutional court No. 27/PUU-XI/2013. Normatively, until now, no changes have been made to the regulation. Meanwhile, the Indonesian House of Representatives as the state organizer, followed up inconsistently. For example, on May 21, 2019, Commission III of the House of Representatives rejected all supreme court nominees proposed by the Judicial Commission. However, on July 11, 2018, Commission III of the House approved two supreme court justices proposed by the Judicial Commission.

\subsection{State Regulation Solution for Non-Compliance Addressat Decision in} Implementing State the Decision testing the Law of the Indonesian Constitutional Court Period 2013-2018

Various scientific treasures have explained that the decision of the Court of Justice is final so that there is no other legal effort to eliminate it. The final meaning in Article 24C paragraph (1) of the 1945 NRI Constitution does give rise to pros and cons. According to Dahlan Thaib, every final verdict should also be binding and cannot be 
repeated. Not clearly mentioning the binding clause in a final ruling would ultimately result in a floating Constitutional Court ruling. ${ }^{15}$ However, according to most experts, the word-final means binding. Maruarar Siahaan said that the final first and final level of the verdict obtained a permanent legal force since it was pronounced in a public open hearing that is erga omnes, which is a ruling that the legal consequences bind all parties. ${ }^{16}$

Apart from the final diction debate of the verdict, in principle, non-compliance with the decision of the Court of Justice is also the same as delaying the realization of justice (justice delayed) or as a rejection of the existence of justice (justice denied). Erwin Chemerinsky said that justice that is postponed could be a justice that is rejected, and in its development, there is no way to predict the consequences that can occur because of this delay. ${ }^{17}$ Based on that, then implementing the decision of the Court of Justice immediately is an obligation because of the final nature of the decision as soon as the implementation of the verdict, will also hasten the presence of certainty, usefulness, and justice of the constitution. In addition, that the law is a combination of consensus and coercion. ${ }^{18}$ Therefore, the decision of the Court of Law which is a form of law must also be interpreted as a compulsion that must be obeyed.

Obedience to the decision of the Court of Justice is an absolute step considering that the state has agreed to make the constitution the supreme. It is said that considering the decision of the Court of Justice of the Republic of Indonesia stemmed from the constitution and interpretation of the articles in the 1945 NRI Constitution. Then, the legislator (The House and President) must submit to the decision of the Court of Justice because there is a principle that should be firmly denied by it, namely the principle of self-respect or self-obedience. The content of the meaning of the principle can be interpreted state organizers must respect the decision of the Court of Justice because there are no known coercive efforts directly through bailiffs as is the case in

\footnotetext{
${ }^{15}$ Dahlan Thaib. (2009). "Ketatanegaan Indonesia Perspektif Konstitusional". 1 ${ }^{\text {st }}$ Edition. Yogyakarta: Total Media. p. 255.

${ }^{16}$ Maruarar Siahaan. (2009). "Peran Mahkamah Konstitusi Dalam Penegakan Hukum Konstitusi", Jurnal Hukum. 3 (16): 359.

${ }^{17}$ Erwin Chemerinsky. (1997). "Justice Delayed is Justice Denied". Berkeley Journal of International Law. 11 (2): 24.

${ }^{18}$ Ahmad Ali dan Wiwie Heryani. (2012). "Menjelajahi Kajian Empiris Terhadap Hukum". Jakarta: Pranada Media Grup. p. 68.
} 
civil legal procedures. ${ }^{19}$ For this, the author tries to suggest several constitutional efforts to realize compliance with the decision of the Court of Justice. The forms of constitutional efforts are as follows:

\section{Delaying the Binding Power of the Award (Judicial Deferral) by Limiting the Time of Necessity of Action}

The meaning of the decision of the Court of The Republic of Indonesia is final, meaning that the decision of the Court of The Republic of Indonesia obtains a permanent legal force since it has been pronounced in a plenary session that is open to the public so that since then the verdict must be implemented. The interpretation of the nature of the decision of the Court of The Republic of Indonesia, certainly not always consistent considering de facto there is a decision of the Court of Justice that takes time to follow up. The need for such time then means delaying the binding power and its enforceability (judicial deferral). Against this, is it justifiable? In practice, delaying the binding power and the enforceability of judicial deferrals are enforced in several countries such as Italy, Germany, Austria, Romania, South Korea, and even the Constitutional Court. ${ }^{20}$

The practice of judicial deferral is thus considered effective because the institution addressat the award has time to prepare the procedure of follow-up of the verdict. However, delays are certainly not without time limits. The constitutional judiciary must still give a time limit on a norm that has been canceled until when it remains valid for later follow-up by the legislator. Thus, the constitutional judiciary does not provide blank checks that give the legislators free interpretation on the right time to follow up.

Departing from the thought of delaying the verdict, the Court of Justice may do it in order to ensure the House or the President follows up the decision. However, the delay of the verdict must be accompanied by a time limit. That is, for example, in the Decision of Constitutional court. No. 4/PUU-XI/2013 concerning implementing

19 Aan Eko Widiarto. (2015). "Ketidakpastian Hukum Kewenangan Lembaga Pembentuk UndangUndang Akibat Pengabaian Putusan Mahkamah Konstitusi". Jurnal Konstitusi. 12 (4): 736.

${ }^{20}$ Bisariyadi. (Ed. Februari, 2017). "Politik Penundaan Pelaksanaan Putusan Atas Nama Demokrasi". Majalah Konstitusi: 74-76. 
presidential thresholds that must be used for general elections in 2019. For that reason, before implementing the 2019 Elections, the legislator followed it up by making it a material content in Law No. 7 of 2017 on Elections.

In order to confirm the delay of the decision accompanied by time limitation, one of them can be done by adding a formulation of new norms through the amendment of Law No. 23 of 2004 jo. Law No. 7 of 2020 on the Constitutional Court (Law of the Constitutional Court), which essentially gives the possibility to the Court of Indonesia to order the postponement of binding power and the validity of the decision accompanied by the limitation of the time of follow-up. If it is felt that there is no need to make changes to the Law quo, then in the future in the decision, the Court of Justice must include a deadline for the implementation of the award within a certain period of months or years. In other words, the judge of the Court of Justice can specifically include the deadline for the implementation of the verdict.

\section{Re-Edification of Judicial Restraint}

The concept of judicial restraint has the spirit to separate the judiciary professionally from the branches of power of other countries to make the judicial body back to its original function, namely to adjudicate or decide cases. The reason for judicial restraint is that the judiciary can easily create a policy model because it modifies existing policies (inkrementalis). ${ }^{21}$ Therefore, it is important to refrain from freely deciding things.

Through judicial restraint, it wants the Court of Indonesia to return to the original state of the original formed as negative legislators, not as a norm-forming institution (positive legislators) which parliamentary institutions play. ${ }^{22}$ It should be pointed out that judicial restraint does not mean that the judiciary should not or refuse to test a law, but rather when and for what issue the judiciary should refrain from. The

\footnotetext{
${ }^{21}$ M.Irfan Islamy (2000). "Prinsip-Prinsip Perumusan Kebijakan Negara”. Jakarta: Bumi Aksara. p. 64-65. ${ }^{22}$ According to Bugaric, positive legislatures are portrayed by parliament, while negative legislative models are portrayed by the constitutional court.. See Bojan Bugaric. (2001). "Courts as Policy Makers: Lessons from Transition", Harvard International Law Journals. 42 (3): 256.
} 
judiciary must measure the degree of authority it has as a parameter of when to act and when to refrain. ${ }^{23}$

How should the Court of Indonesia refrain (self-restraint) in carrying out its authority? then can learn from the Decision of Constitutional Court No. 73/PUUXII/2014 related to the testing of Article 84, Article 97, Article 104, Article 109, Article 115, Article 121, and Article 152 of Law No. 17 of 2004 concerning People Consultative Assembly, the House of Representatives, Regional Representative Council, and Regional People's Representative Assembly. The essence of the matter is to question the filling of the House leadership, which is considered detrimental to the applicant. The decision, rejected by the Court on the grounds of 1) Article 19 paragraph (2) of the 1945 Constitution, determines that the composition of the House of Representatives is regulated by law. According to the Court, it means that how the organization including the mechanism of the election of its leadership is the policy area of the legislator to regulate it; 2) the mechanism of the election of the chairman of the House of Representatives and the fittings of the House of Representatives is an open legal policy (opened legal policy) of the legislator that is not contrary to the 1945 Constitution.

For example, the Court of Justice has built a paradigm that not all law provisions considered not by the 1945 Constitution should be annulled. Indonesia Constitutional court wisely and wisely recognizes that certain problems (testing laws), more appropriate if resolved through the organ of the legislator. Therefore, the Indonesian Constitutional Court refers to it as opened legal policy. In other words, the ruling is a form of self-restraint Indonesian Constitutional court so as not to enter or exceed the authority that the legislator owns.

It is important to point out that judicial restraint is not purely about making the judiciary unable or refusing to test a law. The Court of Justice can still test the law by "exiting" from patron judicial restraint when faced with testing laws that meet the following criteria: 1) violate morality, rationality and intolerant injustice; 2) the law

\footnotetext{
${ }^{23}$ Bisariyadi. (2015). "Yudisialisasi Politik dan Sikap Menahan Diri: Peran Mahkamah Konstitusi dalam Menguji Undang-Undang”. Jurnal Konstitusi, 12 (3): 488.
} 
tested if not progressively decided will cause institutional problems in the form of unenforceable, the rules cause a deadlock and impede the implementation of the performance of the state institution concerned which ultimately causes a loss of constitutionality of citizens; and 3) laws whose content material exceeds the provisions of the limitations that have been determined specifically, imitatively, and expressly clearly in the 1945 Indonesian Constitution.

\section{Collaborative Action and Collective Awareness Development between State Institutions}

It has become a common understanding that the normative provisions of the decision of the Court of Indonesia that has the final consequences must be obeyed. However, the normative clause, of course, is not enough to ensure that the verdict will be followed up in a plenary manner by the institution addressat the verdict. That means that the final verdict is not a variable that can stand on its own. In other words, the decision of the Court of Justice should not be considered an independent variable because it will be counter-productive for the implementation process of the final decision. Suppose the decision of the Court of Justice is only completed on the final normative backrest. In that case, it indicates that the final ruling tends to be understood only as a pure legal ruling. At the same time, when the Court of Justice reads a final ruling, the Indonesian Constitutional court needs political institutions to follow up. The background of the situation led to efforts to carry out two actions, namely collaborative action between the Court of Justice with all state institutions and the development of collective awareness of the position of the decision of the Court of Indonesia as a form of interpretation of the constitution.

First, collaborative action between the Indonesian Constitutional court and all state institutions. The Indonesian Constitutional court should conduct collaborative cooperation between state institutions or strengthen mutual interdependence between the House and the President as a partner state organ given the mandate to follow up the decision of the Court of Representatives. In order to strengthen mutual interdependence between the House of Representatives and the President, intensive cooperation across state institutions driven by the Indonesian Court must be 
conducted. That is, Constitutional court is expected to establish synergistic coordination between the countries implementing the verdict.

The second step is the development of collective awareness of the position of the decision of the Court of Indonesia as a form of interpretation of the constitution. The decision of the Court of The Republic of Indonesia is a product of the interpretation of the constitution. Therefore, there should be no state institutions that bargain not to act on the decision of the Court of The Republic of Indonesia. It should be an understanding and a collective awareness of other state institutions that the decision of the Court of Justice carries a constitutional mandate so that the follow-up to the decision of the Court of Justice must be done properly and immediately. If the collective understanding has been awakened, the actual follow-up to the decision of the Court of Representatives is not solely binding on the House of Representatives or the President. However, it has a dimension of obligation that must be carried out collectively by other state institutions.

\section{Conclusion}

The form of non-compliance by the addressat of the verdict against the decision of the Court of The Republic of Indonesia manifested in 3 (three) forms that have not adhered to normatively, not obeyed praxis and not adhered to normatively and praxis. As a solution to the state regulation, the following is proposed: 1). Delaying the binding power of the award (judicial deferral), but by limiting the time of follow-up of the verdict; 2). Re-affirmation of judicial restraint, namely the Court of Justice must always position itself as a negative legislator, but under certain circumstances, the Court of Justice can act as a legislator (positive legislators); and 3). The Indonesian Constitutional court can collaborate with state institutions to build a common awareness that the existence of a final decision of the Republic of Indonesia is a constitutional interpretation that must be obeyed.

\section{References}

Ali, A., and Heryani, W. (2012). "Menjelajahi Kajian Empiris Terhadap Hukum”. Jakarta: Pranada Media Grup.

Anonymous. (2001). "Kamus Besar Bahasa Indonesia". Jakarta: Departemen Pendidikan Nasional dan Balai Pustaka. 
Arifin, F., et.al., (2019). "Implementasi Putusan Pengujian Undang-Undang oleh Mahkamah Konstitusi 2003-2018”. Jakarta: Indonesian Legal Roundtable.

Asshidiqie, J. (2012). "Perkembangan \& Konsolidasi Lembaga Negara Pasca Reformasi", $2^{\text {nd }}$ edition. Jakarta: Sinar Grafika.

Bachtiar. (2015). "Problematika Implementasi Putusan Mahkamah Konstitusi Pada Pengujian UU Terhadap UUD". Jakarta: Penebar Swadaya Grup.

Bisariyadi. (2015). "Yudisialisasi Politik dan Sikap Menahan Diri: Peran Mahkamah Konstitusi dalam Menguji Undang-Undang”. Jurnal Konstitusi, 12 (3): 488.

Bisariyadi. (Ed. Februari, 2017). "Politik Penundaan Pelaksanaan Putusan Atas Nama Demokrasi”. Majalah Konstitusi: 74-76.

Bugaric, B. (2001). "Courts as Policy Makers: Lessons from Transition", Harvard International Law Journals. 42 (3): 256.

Chemerinsky, E. (1997). "Justice Delayed is Justice Denied". Berkeley Journal of International Law. 11 (2): 24

Huda, N. (2018). "Kekuatan Eksekutorial Putusan Mahkamah Konstitusi”. Yogyakarta: FH UII Press.

Islamy, M.I. (2000). "Prinsip-Prinsip Perumusan Kebijakan Negara”. Jakarta: Bumi Aksara. p. 64-65.

Limbach, J. (2001). "The Concept of the Supremacy of the Constitution". The Modern Law Review. 64 (1):

Mauldi, A.M. (2019). "Menyoal Kekuatan Eksekutorial Putusan Final dan Mengikat Mahkamah Konstitusi”. Jurnal Konstitusi. 16 (2).

Mangunsong, P. M. (1992). "Konvensi Ketatatnegaraan Sebagai Salah Satu Sarana Perubahan UUD". Bandung: Alumni.

Nggilu, N.M. (2019). “Menggagas Sanksi atas Tindakan Constitution Disobedience terhadap Putusan Mahkamah Konstitusi”. Jurnal Konstitusi. 16 (1).

Siahaan, M. (2005). "Hukum Acara Mahkamah Konstitusi Republik Indonesia", $1^{\text {st }}$ Edition. Jakarta: Konstitusi Press.

Siahaan, M. (2009). "Peran Mahkamah Konstitusi Dalam Penegakan Hukum Konstitusi", Jurnal Hukum. 3 (16): 359.

Sutiyoso, B. (2006). "Hukum Acara Mahkamah Konstitusi Republik Indonesia”, Cetakan Pertama, Bandung: PT. Citra Aditya Bakti.

Sutiyoso, B. (2011). "Pembentukan Mahkamah Konstitusi Sebagai Pelaku Kekuasaan Kehakiman di Indonesia." Jurnal Konstitusi, 7 (6): 26.

Soeroso, F.L. (2004). "Aspek Keadilan dalam Sifat Final Putusan Mahkamah Konstitusi", Jurnal Konstitusi. 11 (1): 77.

Soeroso, F.L., et.al., (2013). "Implikasi dan Implementasi Putusan Mahkamah Konstitusi Nomor 5/PUU-X/2012 tentang SBI atau RSBI". Jurnal Konstitusi. 10 (4): 
Syukri, A., Meyrind, R.H., Mohammad, M.A., (2013). "Model dan Implementasi Putusan Mahkamah Konstitusi dalam Pengujian Undang-Undang (Study Verdict of 20032012)". Jakarta: Mahkamah Konstitusi RI.

Syukri, A., Meyrind, R.H., Mohammad, M.A., (2015). "Tindak Lanjut Putusan Mahkamah Konstitusi yang Bersifat Konstitusional Bersyarat Serta Memuat Norma Baru", Jurnal Konstitusi. 12 (3): 653.

Thaib, D. (2009). "Ketatanegaan Indonesia Perspektif Konstitusional". $1^{\text {st }}$ Edition. Yogyakarta: Total Media.

Widiarto, A.E. (2015). "Ketidakpastian Hukum Kewenangan Lembaga Pembentuk Undang-Undang Akibat Pengabaian Putusan Mahkamah Konstitusi". Jurnal Konstitusi. 12 (4): 736. 